(1) Norræna rốôherranefndin

Níu norraenir

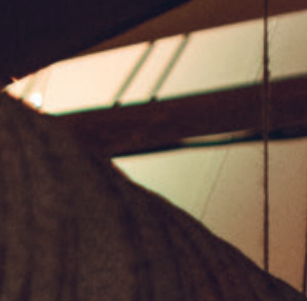

hápunktar ä

árinu $2017 \%$

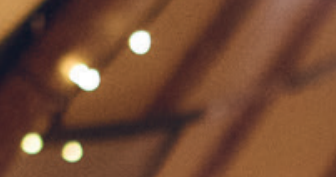

Ding

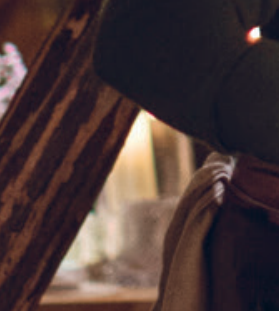

$\bullet$
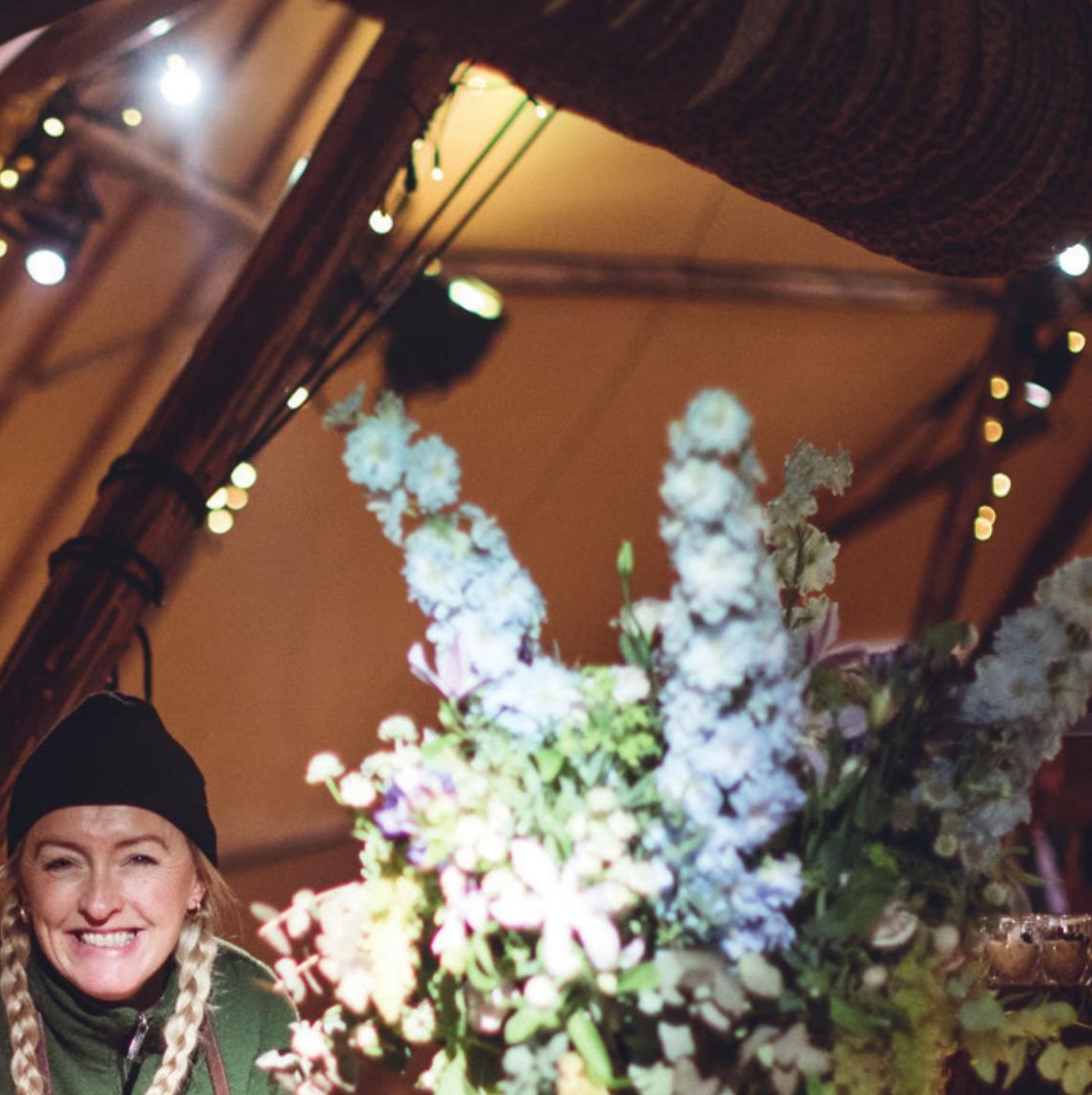

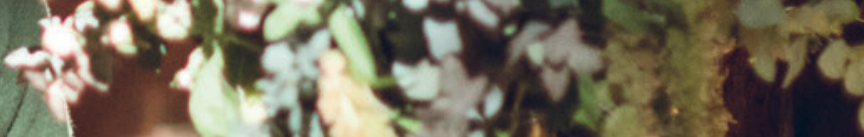
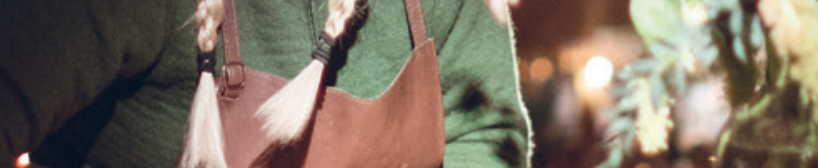

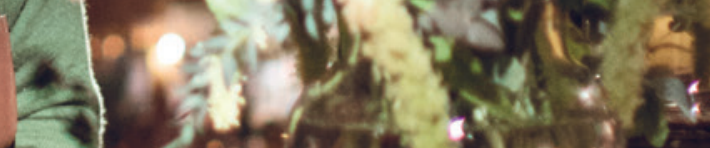

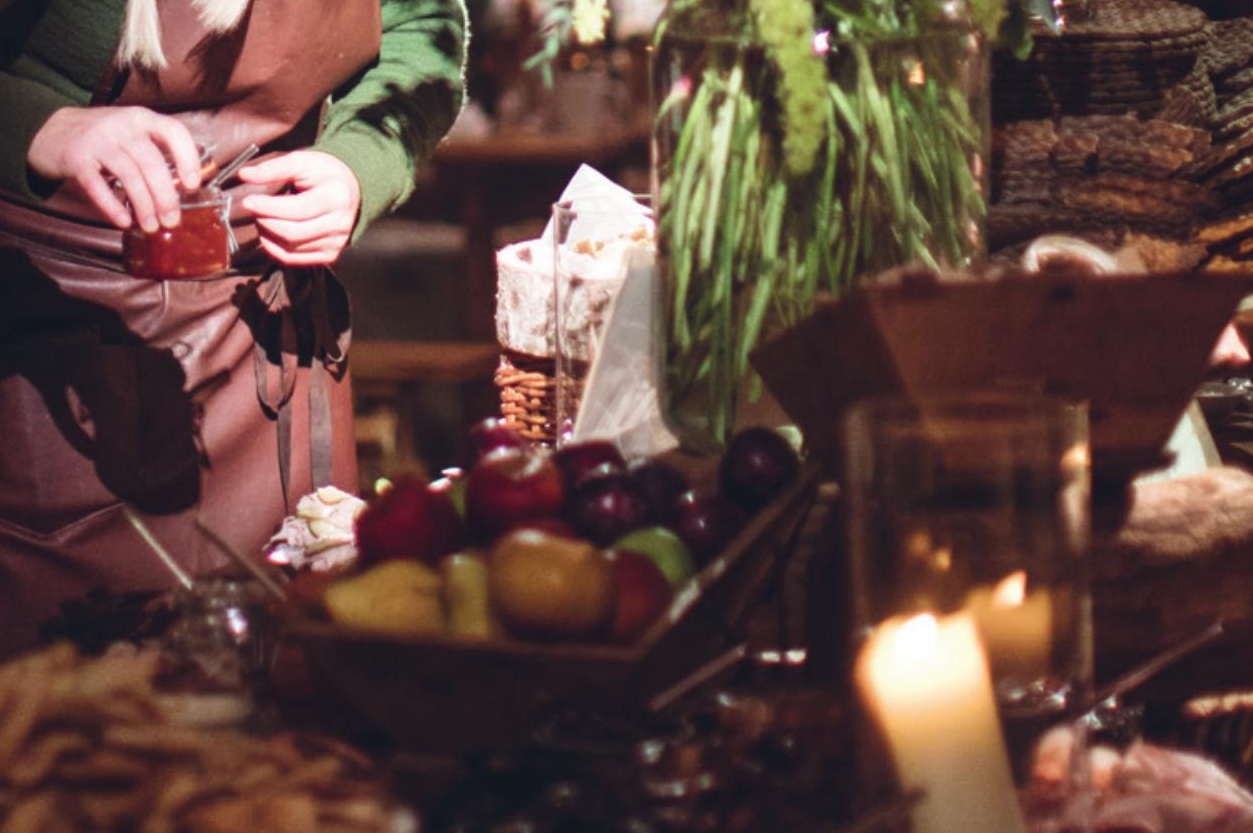


Níu norrænir hápunktar á árinu 2017

Ársskýrsla Norrænu ráőherranefndarinnar

ANP 2018:745

ISBN 978-92-893-5532-2 (PRINT)

ISBN 978-92-893-5533-9 (PDF)

ISBN 978-92-893-5534-6 (EPUB)

http://dx.doi.org/10.6027/10.6027/ANP2018-745

@ Norræna ráðherranefndin 2018

Umbrot: Louise Jeppesen

Kápumynd: Tina Stafrén

Prentun: Rosendahls

Printed in Denmark

\section{Norrænt samstarf}

Norræna samstarfið er eitt umfangsmesta svæðasamstarf í heiminum. Að̋ samstarfinu koma Danmörk, Finnland, Ísland, Noregur og Svipjóð auk Álandseyja, Færeyja og Grænlands.

Norræna samstarfið er pólitískt, efnahagslegt og menningarlegt og skiptir miklu í evrópsku og alpjóðlegu samstarfi. Löndin vinna saman að pví að marka Norð̆urlöndum stöðu í öflugri Evrópu.

Með̌ norrænu samstarfi er unnið að̃ pví að̃ gæta hagsmuna svæðisins og efla norræn gildi í hnattrænum heimi.

Sameiginleg gildi landanna styrkja stöðuu Norőurlanda og skipa peim meðal peirra svæða í heiminum par sem nýsköpun og samkeppnishæfni er mest.

Norræna ráôherranefndin

Nordens Hus

Ved Stranden 18

DK-1061 København K

www.norden.org

Sækja útgefið efni: www.norden.org/nordpub 


\section{Efnisyfirlit}

$07 \quad$ Níu norrænir hápunktar á árinu 2017

09 Norrænar lausnir á hnattrænum viơfangsefnum

11 Árið 2030 póll í hæo

13 Sterk nærvera á 23. loftslagsráôstefnunni

15 Samstarfiò nýtur mikils stuônings

17 Aukin áhersla á orkumálasamstarf

19 Ný sérskipuò rádherranefnd um stafræn málefni

$21 \quad$ Norræn menning sló í gegn í Lundúnum

23 Stjórnsýsluhindranarádið fær aukið̃ starfsumboð

25 Umbótastarfið Nytt Norden skilar árangri 
Katherine Richardson, Gunhild Stordalen og Fadumo Dayib, sem allar eru albjóðlega pekktar, tóku

pátt í að hleypa forsætisráðherraverkefninu af stokkunum í Björgvin í maí árið 2017. Hér má sjá pær

með forsætisráðherrunum Bjarna Benediktssyni, Lars Løkke Rasmussen, Stefan Löfven, Ernu Solberg

og Juha Sipilä ásamt Dagfinn Høybråten, framkvæmdastjóra Norrænu ráðherranefndarinnar.

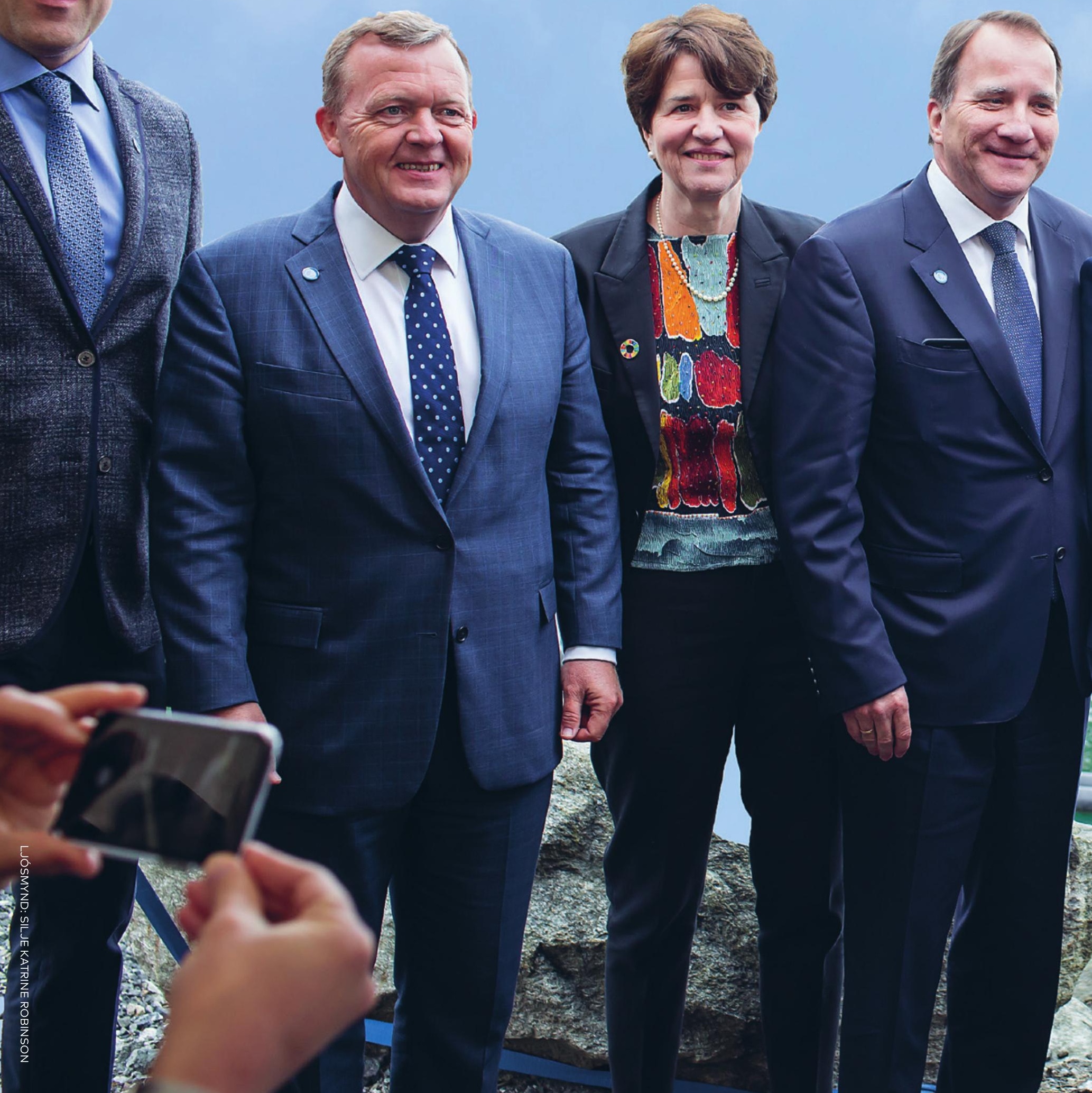




\section{Saman erum}

\section{viő öflugri}

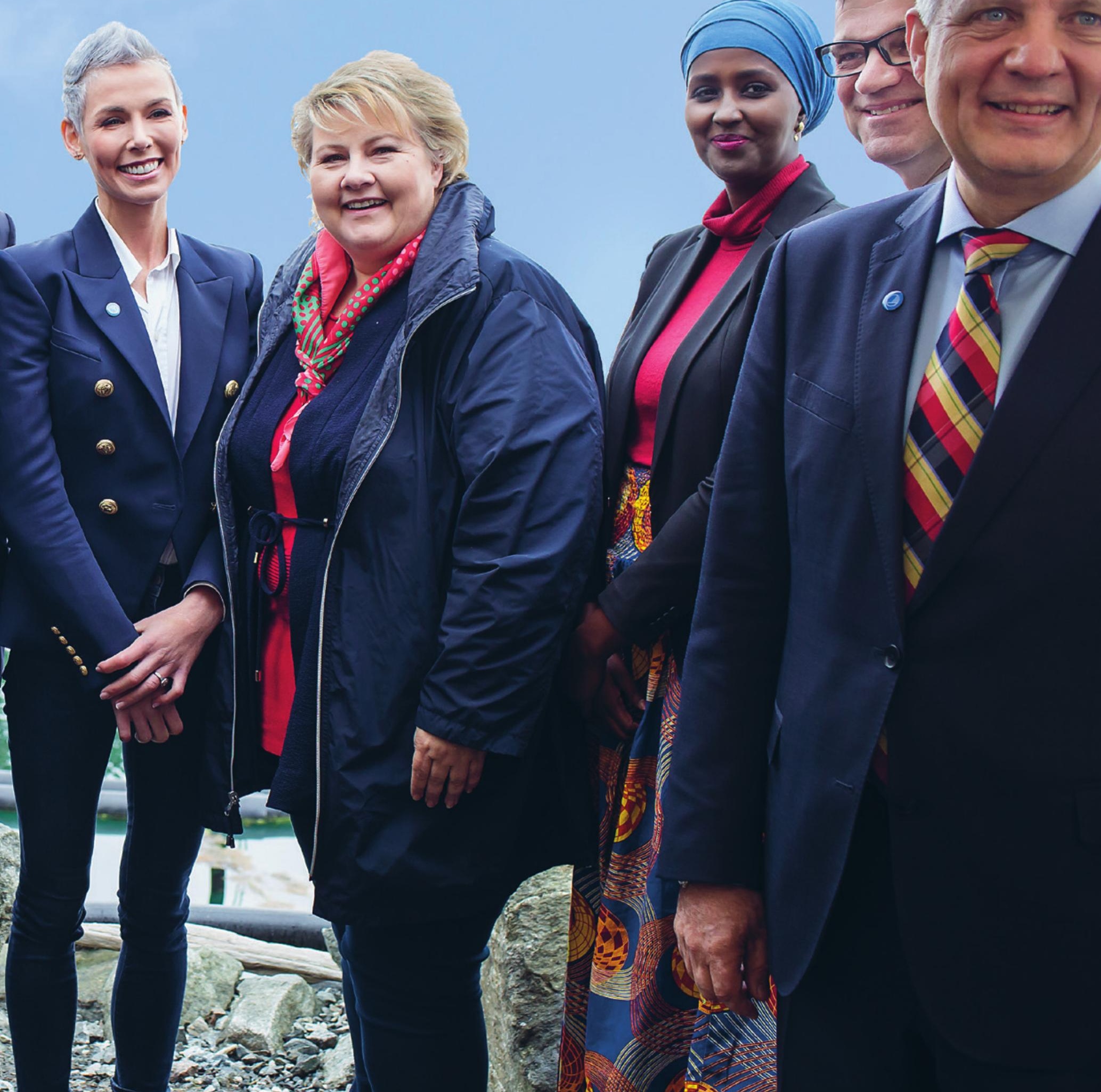



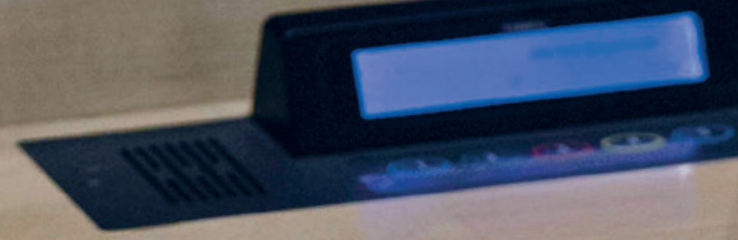

ras $=0$
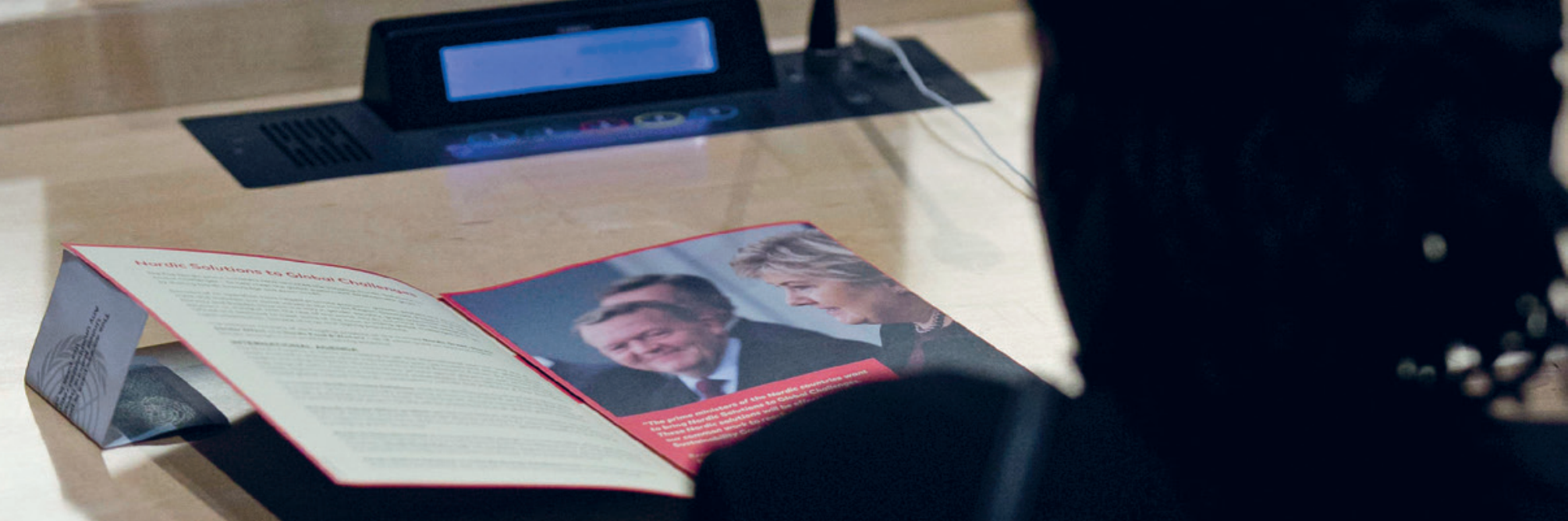

s.8.

1 


\section{Níu norrænir hápunktar á árinu 2017}

Verkefni forsætisráoherranna um norrænar lausnir á hnattrænum viðfangsefnum, skýrsla um orkumál sem varðar veginn að auknu samstarfi á bví sviði, áhersla ráðherranna á samstarf um stafræn málefni og norræn menning sem slær í gegn í Lundúnum. Petta er aðeins brot af peim verkefnum og viðburðum sem starfsemi Norrænu ráôherranefndarinnar snerist um á árinu 2017.

Afrekaskrá ársins 2017 er löng. Ekki er nokkur leið að telja upp allt sem var á dagskrá í stuttri samantekt um árið. Pess vegna höfum við hjá Norrænu ráðherranefndinni tekið út nokkur efnissvið sem skipuðu sérstakan sess á árinu 2017, að ógleymdum aðskiljanlegustu verkefnum sem ekki er unnt að nefna, en öll stuðla pau að auknu norrænu samstarfi í pví augnamiði að verða að lokum öllum almenningi á Norðurlöndum til hagsbóta.

Í samantekt okkar um árið 2017 höfum við ákveðið að kynna níu hápunkta sem bera vitni framtíðarsýn Norrænu rádherranefndarinnar um Norðurlönd sem eru skapandi, laus við stjórnsýsluhindranir, sýnileg og opin. Lesið endilega meira um pá hér að neðan.

Dagfinn Høybråten

framkvæmdastjóri

Norrænu rádherranefndarinnar 


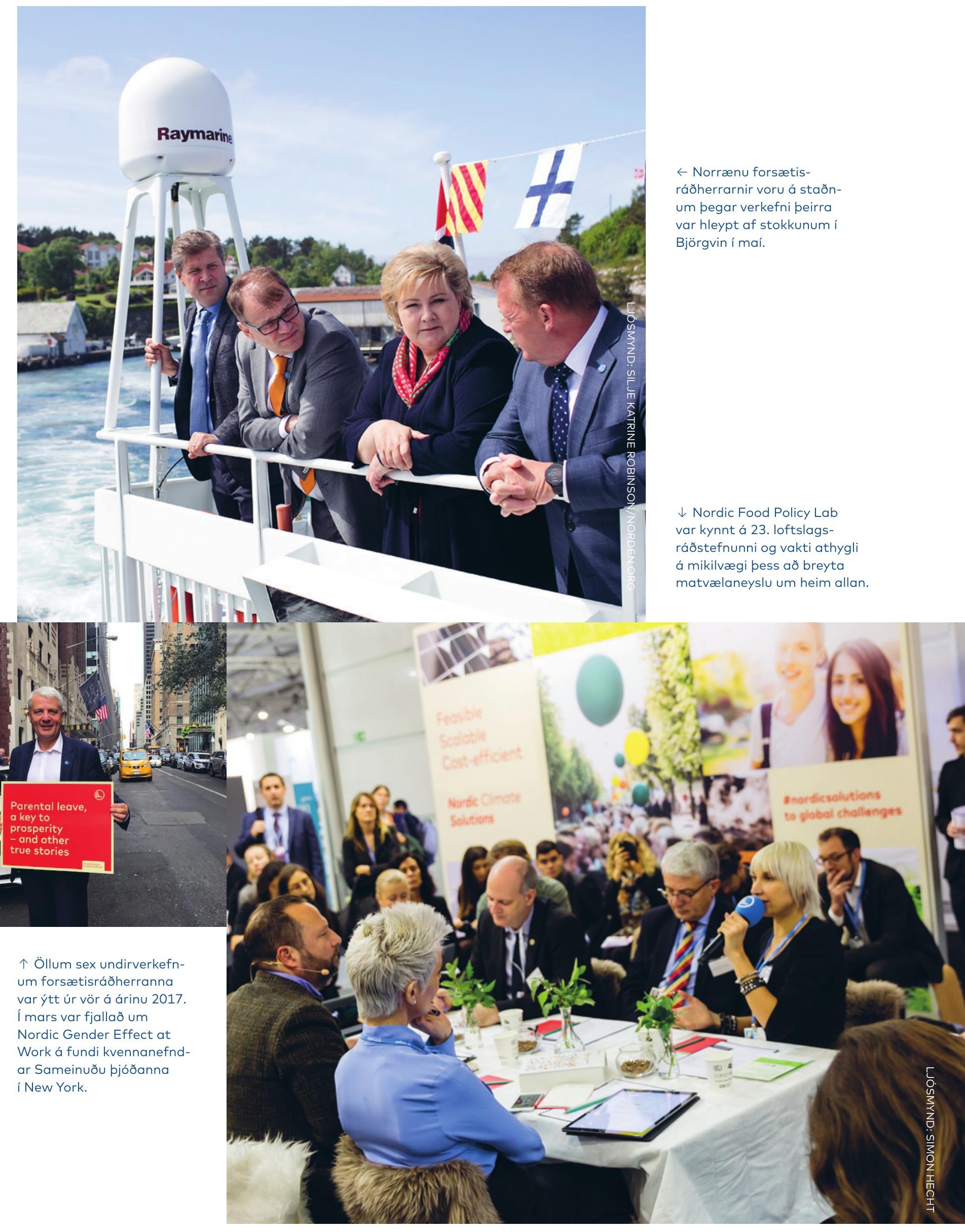




\section{Norrænar lausnir á hnattrænum viơfangsefnum}

Hinn 30. maí 2017 var verkefni

forsætisráðherranna Norrænar lausnir

á hnattrænum viðfangsefnum hleypt af stokkunum við athöfn í Björgvin par sem allir forsætisráðherrarnir fimm voru viðstaddir. Par með hófst stórátak norrænu ríkisstjórnanna í að bjóða heimsbyggðinni upp á lausnir á fjölpættum hnattrænum verkefnum, ekki síst á grunni heimsmarkmiðanna um sjálfbæra próun og Dagskrár 2030. Verkefnið er einkar vel fallið til útbreiðslu með pá afstöðu í huga að sjálfbær próun parf ekki að vera í mótsögn við hagvöxt. Áætlaður fjárhagsrammi pessa verkefnis forsætisráðherranna fyrir tímabilið 2017-2019 nemur u.p.b. 74 milljónum danskra króna. Hann skiptist niður á sex flaggskipsverkefni sem er ætlað að miðla norrænni pekkingu um allan heim um sjálfbært borgarskipulag, svæðisbundið orkumálasamstarf, jafnrétti á vinnumarkaði, sjálfbæra matvælaframleiðslu og snjallar velferðar- og loftslagslausnir. Verkefnin ná yfir mörg heimsmarkmiðanna sautján í Dagskrá 2030 og eru líkleg til að hafa mikið um pað að segja að markmiðin náist fyrir árið 2030.

Verkefni forsætisráðherranna var árangursríkt pegar á fyrsta árinu.

Til dæmis var gefin út hvítbók undir merkjum Nordic Sustainable Cities um pað sem prýðir sjálfbærar borgir á Norðurlöndum. Bókin var kynnt á Nordic Edge-sýningunni um snjallar borgir í Stafangri í september. Verkefnið kom einnig við sögu á alpjóðlegum ráðstefnum í Barselóna og Mexíkó. Á vegum verkefnisins hefur einnig verið unnið með norrænu útflutningssamtökunum að pví að finna fimmtán borgir víðs vegar um heiminn sem munu innan skamms ráðast í miklar fjárfestingar og eru pess vegna sóknarfæri fyrir norræn fyrirtæki.

Í mars var annað flaggskipsverkefni, Nordic Gender Effect at Work, kynnt á fundi kvennanefndar SP, CSW61, í New York. Verkefnið var einnig á leiðtogaviku SP í september og á alpjóðlegri ráðstefnu í Kaupmannahöfn í október.

Verkefnið Nordic Energy Solutions hófst með pví að Austur-Afríka var valin sem hentugt landssvæði fyrir norrænar orkulausnir. Ástæðan fyrir valinu eru orkulindir á svæðinu sem parfnast ýmissa tæknilausna sem Norðurlönd búa yfir.

Nordic Welfare Solutions myndaði á fyrsta starfsári sínu starfshópinn Nordisk Export Task Force (NETF) til að annast sameiginleg norræn útbreiðsluverkefni. Var ákveðið að hópurinn léti fyrst til sín taka í Toronto í Kanada.

\section{Flaggskipsverkefnið Nordic Climate Solutions} er tvískipt. Nordic Green to Scale 2 hefur аð markmiði að kanna hvernig norrænar loftslagslausnir koma að notum í stærra samhengi. Á 23. loftlagsráðstefnunni voru kynntar bráðabirgðaniðurstöður verkefnisins og einnig hins verkefnisins, FFSR - Fossil Fuel Subsidy Reform, sem snýst um að afnema niðurgreiðslur á jarðefnaeldsneyti í fjölpjóðlegu samstarfi.

Pá tók Nordic Food Policy Lab pátt í 23. loftslagsráðstefnunni og vakti athygli á mikilvægi pess að breyta matarvenjum á hnattræna vísu. Auk pess hefur verkefnið kynnt norræna matvælastefnu á viðburðum meðal annars í Hollandi, Skotlandi, New York og Lundúnum. 


\section{Árið 2030 póll íhæd}

Á árinu 2017 ákvað Norræna ráðherranefndin að setja Dagskrá 2030 og heimsmarkmiðin sautján í algjöran forgang. Framvegis mun tekið tillit til markmiðanna í allri starfsemi ráðherranefndarinnar. Málefnið var formlega tekið á dagskrá í september pegar norrænu samstarfsráðherrarnir sampykktu áætlunina 2030-kynslóðin sem á að efla samstarfið um sameiginlegar áskoranir landanna innan ramma heimsmarkmiðanna. 2030-kynslóðin á ásamt verkefni forsætisráðherranna að vera grundvöllur vinnu ráðherranefndarinnar að Dagskrá 2030.

Í áætluninni verður lögð sérstök áhersla á sjálfbæra neyslu og framleiðslu, sem hefur sýnt sig að er svið sem Norðurlönd verða að leggja mikið upp úr eigi löndin að ná markmiðunum.

Með áætluninni verður greitt fyrir samstarfi og pekkingarmiðlun milli mismunandi markhópa og stefnumótandi aðila á Norðurlöndum.
Meginmarkmið áætlunarinnar eru prjú. Pau eru að:

- Tryggja að starf Norrænu ráðherranefndarinnar eigi pátt í að hrinda Dagskrá 2030 í framkvæmd með pólitískum áherslum og viðeigandi verkefnum.

- Taka pátt í og miðla pekkingu á Dagskrá 2030 á Norðurlöndum.

- Vekja athygli á starfi Norrænu ráðherranefndarinnar að Dagskrá 2030 á Norðurlöndum og albjóðlega.

Ekki stendur til að samhæfa innleiðingu heimsmarkmiðanna ílöndunum heldur greiða fyrir pví að pau komist í framkvæmd. Pað er hægt að gera með viðeigandi greiningum, pekkingarmiðlun og umræðum, próun aðgerða og hvatningu til félagasamtaka, einkageirans, tengslaneta fræðimanna og æskulýðssamtaka.

2030-kynslóðin á einkum að laða börn og ungmenni til samstarfs til að pau geti beitt sér fyrir breytingum í starfseminni í heild. 


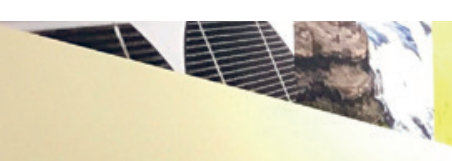

Feasible

Scalable

\section{Cost-efficient}

Nordic Climate

\section{Solutions}




\section{Sterk nærvera á 23. loftslagsrádstefnunni}

Norræna ráðherranefndin tók pátt í umfangsmiklu verkefni á 23. loftslagsráðstefnu SP sem fram fór í Bonn 6.-17. nóvember 2017. Norrænu löndin voru með sameiginlegan sýningarskála alla ráðstefnuna í umsjón ráðherranefndarinnar. Á dagskránni voru sextíu viðburðir par sem kynntar voru sjálfbærar norrænar loftslagslausnir.

\section{„Norrænu löndin hafa ekki svör við öllu. Við höfum aftur á móti langa reynslu af bví að̃ setja fram tilmæli, grundvölluð á} pekkingu, sem markaðurinn og neytendurnir taka til eftirbreytni aơ mjög miklu leyti. Við höfum líka sterkan vilja - og umboð allra norrænu forsætisráðherranna - til að láta til okkar taka í pessum mikilvægu alpjóðlegu umræơum um hvernig hægt er að̃ skapa jörð̃inni okkar betri framtíð. Að sitja hjá væri óviðunandi."

DAGFINN HØYBRÅTEN, FRAMKVÆEMDASTJÓRI NORRAENU RÁĐHERRANEFNDARINNAR
Á peim tíu dögum sem ráðstefnan stód sýndu Norðurlönd ótal dæmi pess hvernig Norræna ráðherranefndin, stofnanir hennar og samstarfsaðilar starfa saman að grænum umskiptum. Viðburðunum var skipt upp í pemadaga með nýju umfjöllunarefni á hverjum degi, meðal annars um lífhagkerfið, matvæli, norðurskautssvæðið og orkumál.

Í norræna skálanum var riðið á vaðið með Nordic Youth Day 6. nóvember par sem páttur ungs fólks í starfi að loftslagsmálum var í brennidepli. Ungir sendiherrar norrænna loftslagslausna voru pátttakendur á loftslagsráðstefnunni allan tímann til að hleypa krafti í loftslagsumræðurnar á Twitter.

Dagskráin í sýningarskála Norðurlanda og hönnun hans hlaut góðar móttökur. Mat á pátttökunni á loftslagsráðstefnunni sýnir að 72 prósentum gesta pótti norræna dagskráin eiga erindi eða mikið erindi og 69 prósentum fannst gæði dagskrárinnar mikil eða mjög mikil. Meðalfjöldi gesta á viðburðina var 42. 


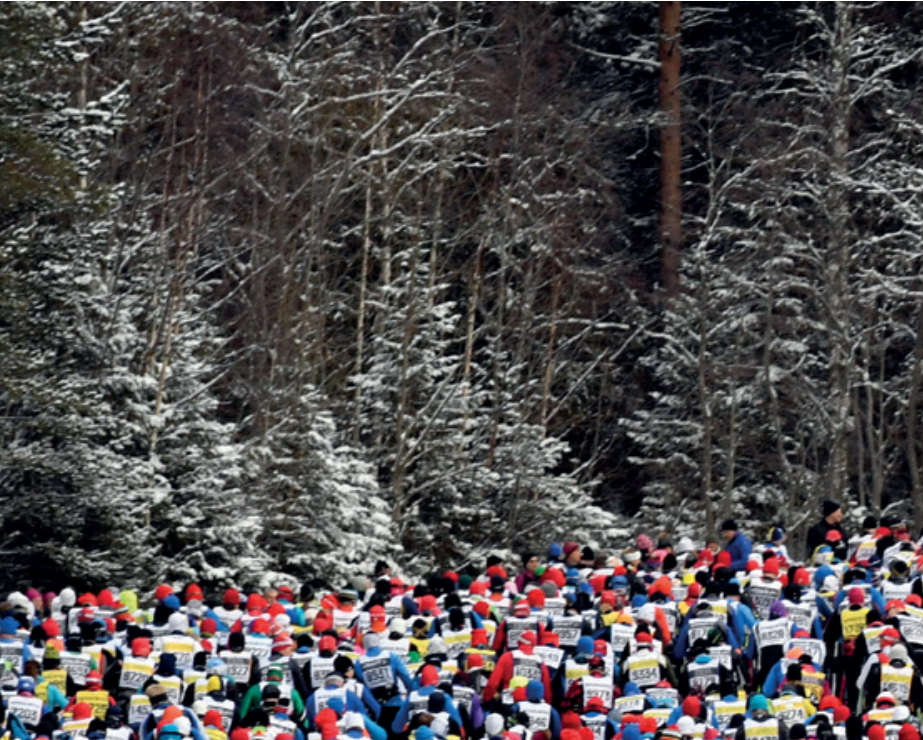

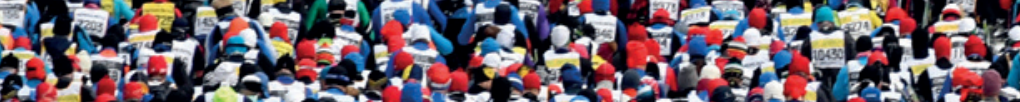

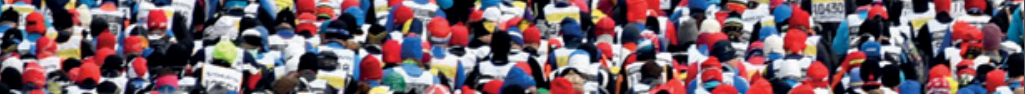
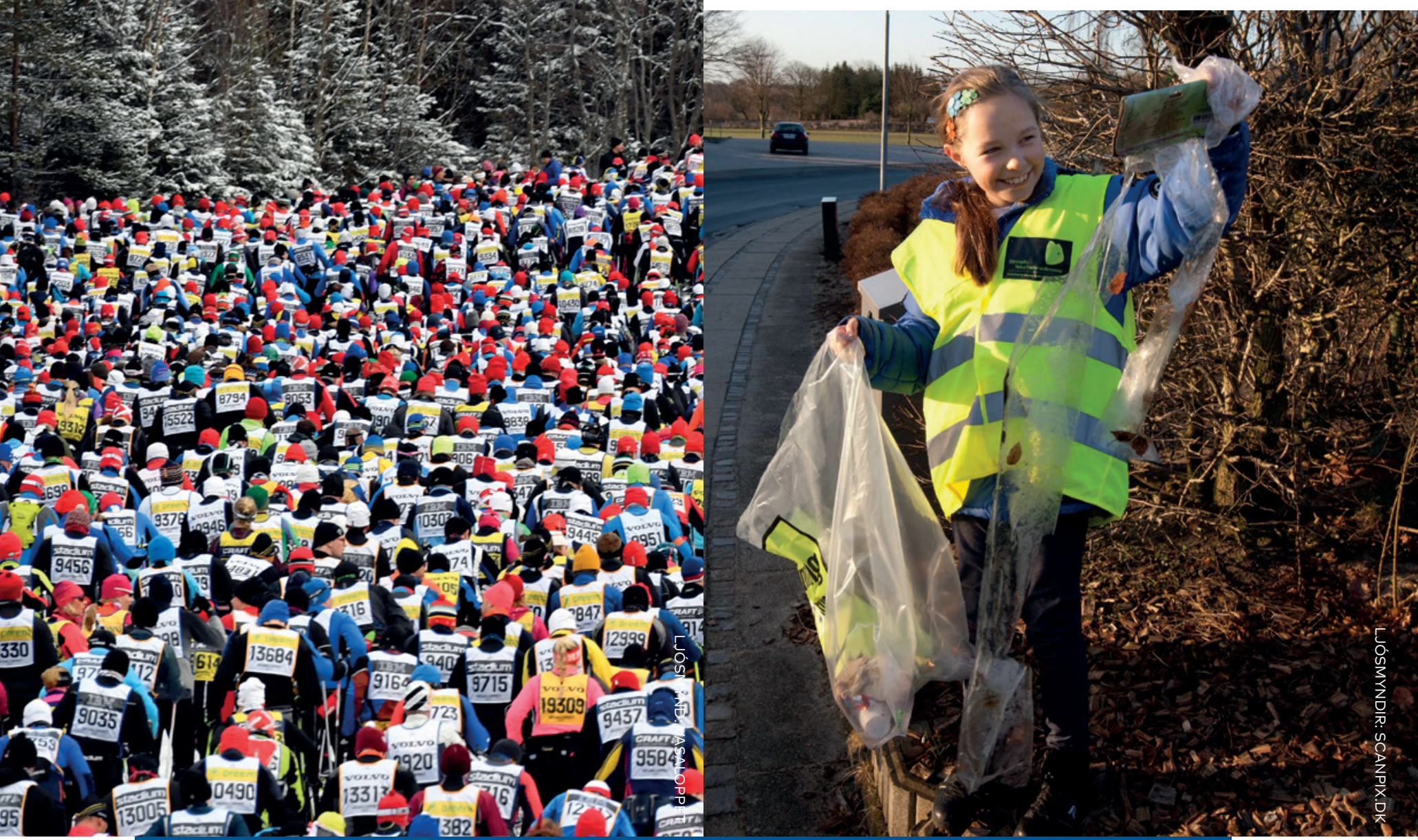

„Sé litiố á svæôiố í heild eru Norôurlönd heimsmeistarar pegar kemur aố félagslegu trausti meốal almennings. Ítarleg fræôirit á pessu sviôi gefa til kynna aỗ mikiô félagslegt traust sé ef til vill eitt út af fyrir sig dýrmætasta eign sérhvers samfélags. Pess vegna má líta á traustiô, eins og skilja má af titli skýrslunnar, sem nokkurs konar gull norrænu landanna." 


\section{Samstarfiò nýtur mikils stuônings}

Í ársbyrjun 2017 setti Norræna ráðherranefndin á fót eigin greiningarstofu í peim tilgangi að auka greiningarmöguleika sína og um leið pólitískan áhuga á starfsemi ráðherranefndarinnar. Á fyrsta starfsárinu gaf stofan út prjár skýrslur, par á meðal Ett värdefullt samarbete (Dýrmætt samstarf) en hún byggðist á skoðanakönnun meðal almennings á Norðurlöndum um álit peirra á norrænu samstarfi.

Skýrslan sýndi að Norðurlandabúar eru afar jákvæðir gagnvart samstarfinu. Meira en 90 prósent telja norrænt samstarf mikilvægt eða mjög mikilvægt og par af svara nærri 60 prósent að pað sé mjög mikilvægt.

Skýrslan sýnir einnig að skoðun íbúanna á pví hvað norrænu löndin eigi helst að vinna saman að hefur breyst á undanförnum áratug. Nú eru varnar- og öryggismál efst á lista. Í sambærilegri könnun árið 2008 töldu íbúar Norðurlanda að baráttan gegn brotastarfsemi pvert á landamæri skipti mestu. Önnur málefni sem talin eru mikilvæg eru samstarf um menntamál, heilbrigðis- og félagsmál, efnahagsmál og mál varðandi loftslag og umhverfið.

Könnunin var gerð í samstarfi Norrænu ráðherranefndarinnar og Norðurlandaráðs og var hún kynnt á Norðurlandaráðspinginu í Helsinki í október.
Í júní kom út skýrslan Tillit - det nordiska guldet (Traust - norræna gullið) par sem fjallað er um félagslegt traust á Norðurlöndum sem einstakt fyrirbæri i alpjóðlegum samanburði. Par má meðal annars lesa um hvaða pýðingu traust hefur fyrir góðan almannahag, lága afbrotatíðni og hamingju. Skýrslan vakti enda athygli fjölmiðla á Norðurlöndum og víðar.

Priðja skýrsla greiningarstofunnar nefnist Är Norden bäst i världen? (Eru Norðurlönd best í heimi?) og fjallar hún um að Norðurlönd sem heild séu meðal peirra svæða í heiminum sem bestum árangri hafa náð á mörgum sviðum. Aðdragandinn að skýrslunni var sá að hagurinn hafði vænkast umtalsvert á undanförnum árum samkvæmt ýmsum alpjóðlegum vísitölum sem öðlast höfðu viðurkenningu og veruleg áhrif.

Skýrslan sýndi að Norðurlönd koma einstaklega vel út pegar mæld er hamingja, hagsæld, lítil spilling, fjölmiðlafrelsi og jafnfrétti. Í henni er einnig að finna skýringar á bví hvers vegna Norðurlönd fá svona háa einkunn íýmsu tilliti. 

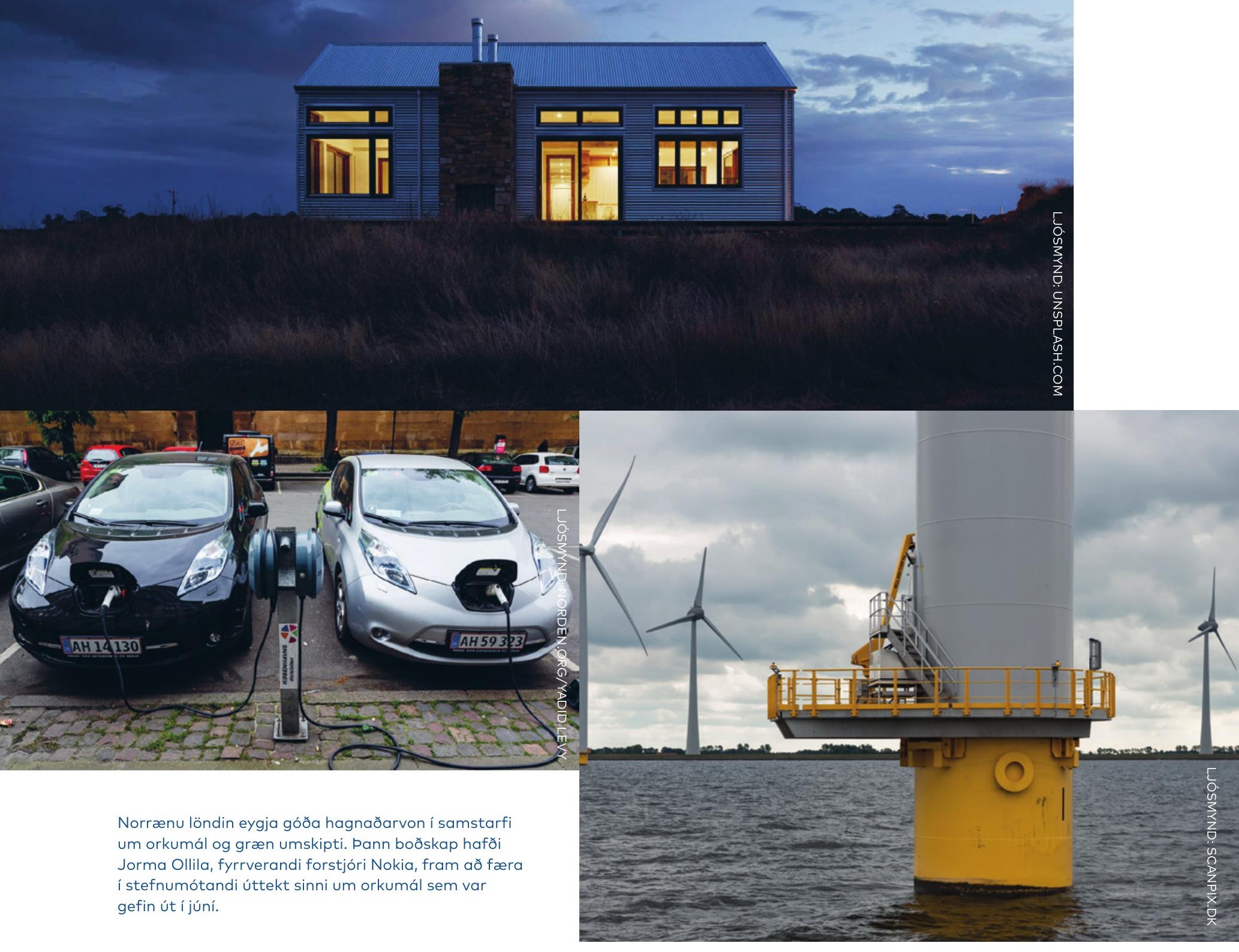


\section{Aukin áhersla á orkumálasamstarf}

Norrænt samstarf um orkumál var ofarlega á baugi á árinu 2017. í júní kynnti Jorma Ollila, fyrrverandi forstjóri Nokia, stefnumótandi úttekt sem hann hafði tekið saman, Norrænt orkumálasamstarf: Öflugt í dag - enn öflugra á morgun, en í henni leggur hann fram fjórtán tillögur um hvernig norrænt samstarf um orkumál ætti að próast næstu fimm til tíu ár. Norrænu orkumálaráðherrarnir tóku Ollilaskýrsluna fyrir á fundi i Ósló í nóvember og ákváðu að vinna áfram með nokkrar tillögur hennar.

Meðal annars ákváðu peir að efla samstarfið um orkumál á norrænum og evrópskum vettvangi og voru á einu máli um að Norðurlönd ættu einnig framvegis að vísa veginn fyrir grænan hagvöxt í samræmi við aðalatriðin í boðskap Jorma Ollila eins og hann kemur fram í skýrslunni. Orkumálaráðherrarnir sampykktu einnig að setja samnorrænar orkurannsóknir í algjöran forgang. Pá ákváðu peir að koma á árlegum samráðsvettvangi um málefni raforkumarkaðarins og orkumálastefnu í peim tilgangi að bæta svæðisbundið samstarf á sviðinu og efla norræn upplýsingaskipti. Samráð petta á að hefjast haustið 2018.
Á fundi sínum í Ósló sampykktu ráðherrarnir nýja norræna samstarfsáætlun í orkumálum sem á að vísa veginn í norrænu samstarfi um orkumál næstu fjögur ár, 2018-2021. Auk pess er stefnt að pví að vinna áfram með skýrslu Ollila í áföngum.

Ollilaskýrslan var oft til umfjöllunar á árinu 2017, meðal annars á námsstefnum á fundum fólksins sem haldnir eru ílöndunum á sumarmánuðum. Hún var einnig á dagskrá á ráðstefnum stefnumótandi aðila, svo sem á pingi Norðurlandaráðs um haustið. Henni voru gerð góð skil i norrænum ríkismiðlum.

Ollilaskýrslan er ein af mörgum stefnumótandi úttektum sem hafa verið gerðar eða verða gerðar með pað fyrir augum að gera Norrænu ráðherranefndina skilvirkari og auka vægi norræns samstarfs. Rádherranefndin lét einnig hefja úttektir á sviði umhverfis, löggjafar og félagsmála á árinu 2017. 
-

0

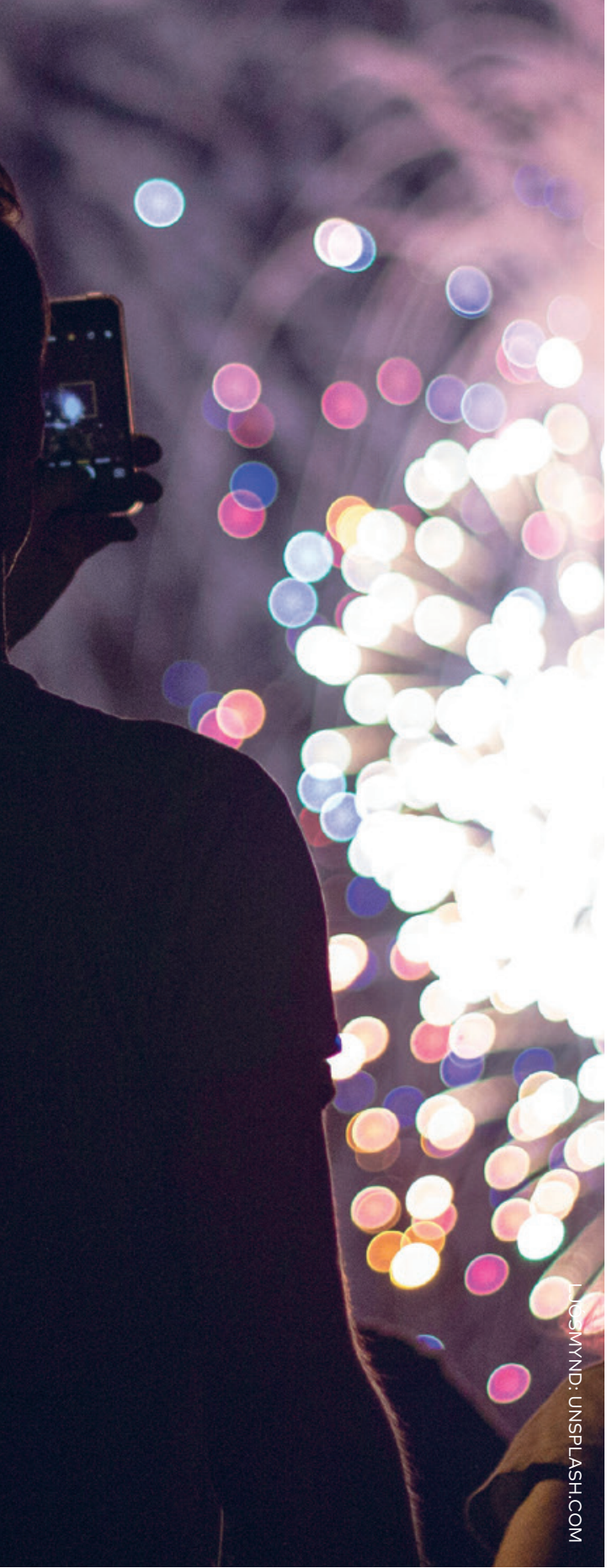




\section{Ný sérskipuõ ráôherranefnd um stafræen málefni}

Stafræn væðing var sett á oddinn í norrænu samstarfi árið 2017 og á fundi í Sommarøy í Noregi i júní ákváðu samstarfsráðherrarnir að skipa um ákveðinn tíma svonefnda ad hoc ráðherranefnd, MR-DIGITAL, fyrir tímabilið 20182020. MR-DIGITAL á að leiða áfram og samhæfa samstarfsaðgerðir um stafræn málefni. Fyrsti ráðherrafundurinn fór fram í desember og par tóku einnig ráðherrar Eystrasaltsríkjanna pátt.

„Umskipti á Norðurlöndum

og Norðurlönd í Evrópu eru tvö meginpemu formennskuáætlunar Noregs í Norrænu ráôherranefndinni. Nánara svæðisbundið samstarf um stafræn málefni innan opinbera geirans og einkageirans á að auka samkeppnishæfni og styðja viơ evrópskt samstarf á svið̛inu."

FRANK BAKKE-JENSEN, SAMSTARFSRÁĐHERRA NOREGS PEGAR LANDIĐ GEGNDI FORMENNSKU Í NORRAENU

RÁĐHERRANEFNDINNI ÁRIĐ 2017
Pessi nýja ráðherranefnd á að einbeita sér að pví að próa stafrænan innri markað Norðurlanda og Eystrasaltsríkjanna í samræmi við yfirlýsingu um aukið samstarf landanna um stafræna væðingu sem sampykkt var á fundi í Ósló í apríl.

Samstarfinu er ætlað að efla stafræna væðingu opinberrar stjórnsýslu milli landa og í atvinnulífinu auk pess að örva próun innri markaðar á svæðinu. Markmiðið er að styrkja stafræna væðingu á svæðinu í heild og styðja í leiðinni við starf ESB að stafrænni próun. Samstarfið beinist að tveimur höfuðsviðum: Próun norrænna rafrænna skilríkja (e-id) og áætlun um útfærslu á fimmtu kynslóð farsímatækni (5G) á Norðurlöndum og í Eystrasaltsríkjunum. 


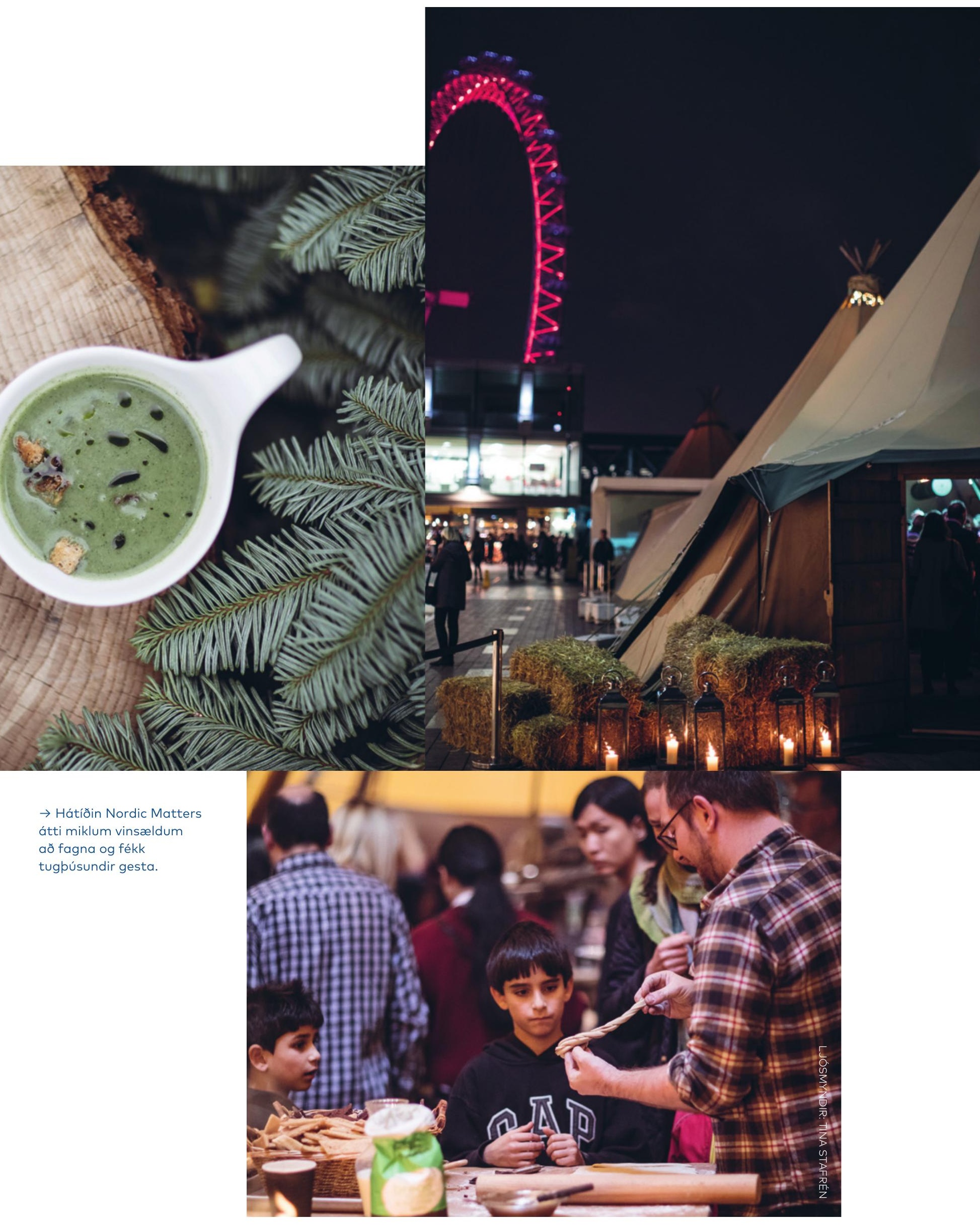




\section{Norræn menning sló í gegn í Lundúnum}

Menningarhátíðin Nordic Matters fór fram allt árið í Southbank Centre í Lundúnum. Á hátíðinni tókst að sýna umfang og allar bestu hliðar norrænnar menningar en hún var stórátak norrænu menningarmálaráðherranna á árinu 2017. Hátíðin sló í gegn og gestir hennar skiptu tugum púsunda. Opnunarhelgina komu hvorki meira né minna en 60 púsund gestir og sannaðist par strax að áhuginn á norrænu hátíðinni var mikill.

Meðan á hátíðinni stóð var gestum boðið upp á norrænan mat, norrænar bókmenntir og tónlist, meðal annars ABBA, kórsöng og fjöldasöng, norræna hönnun, grænlenskan polka, legókubbaverkefni, gufubað og múmínálfa svo að fátt eitt sé nefnt.

Af mörgu er að taka á efnisskránni en nefna má sýninguna Adventures in Moominland sem fékk tugpúsundir gesta og var framlengd hvað eftir annað. Barnamenningarhátíðin Imagine, sem bar sömuleiðis sterk norræn einkenni, laðaði til sín 130 púsund gesti á ýmsa ókeypis viðburði. Á hátíðina WOW (Women of the World), par sem efnt var til umræðna, sýninga og tónleika, m.a. með Reykjavíkurdætrum, Sandi Toksvig og Anne Sofie von Otter, kom næstum hálf milljón gesta.
Á árinu voru einnig haldnir í allra fyrsta sinn hinir heimspekktu tónlistardagar fyrir listræna tónlist, Nordic Music Days, á Southbank Centre, með íslenska tónskáldinu Önnu Porvaldsdóttur og finnska fiðluleikaranum Pekka Kuusisto meðal annarra. Fjölmargir norrænir rithöfundar tóku pátt í Nordic Matters í október, par á meðal Ulla-Lena Lundberg, Per Olov Enquist, Dorthe Nors, Jonas Hassen Khemiri, Sissal Kampmann, Kjell Askildsen og Sigbjørn Skåden.

Hátíðahöldin á Southbank Centre hafa aukið pekkinguna á norrænni menningu og norrænum gildum eins og jafnrétti og skýrri barna- og ungmennavídd. Til dæmis má nefna að Southbank Centre hefur frá pvi í nóvember 2016 kannað pekkingu gesta á norrænni menningu. Í upphafi tengdu gestir Norðurlönd einna helst við víkinga en í lok ársins 2017 bar meira á hugtökum á borð við jafnrétti, huggulegheit og múmínálfa.

Nordic Matters lauk með pompi og pragt pegar ABBA-sýningin Super Trouper var sett upp, sýning með leiðsögn par sem skyggnst var bak við tjöldin hjá sænsku popp-hljómsveitinni og skoðuð áður ópekkt gögn. 

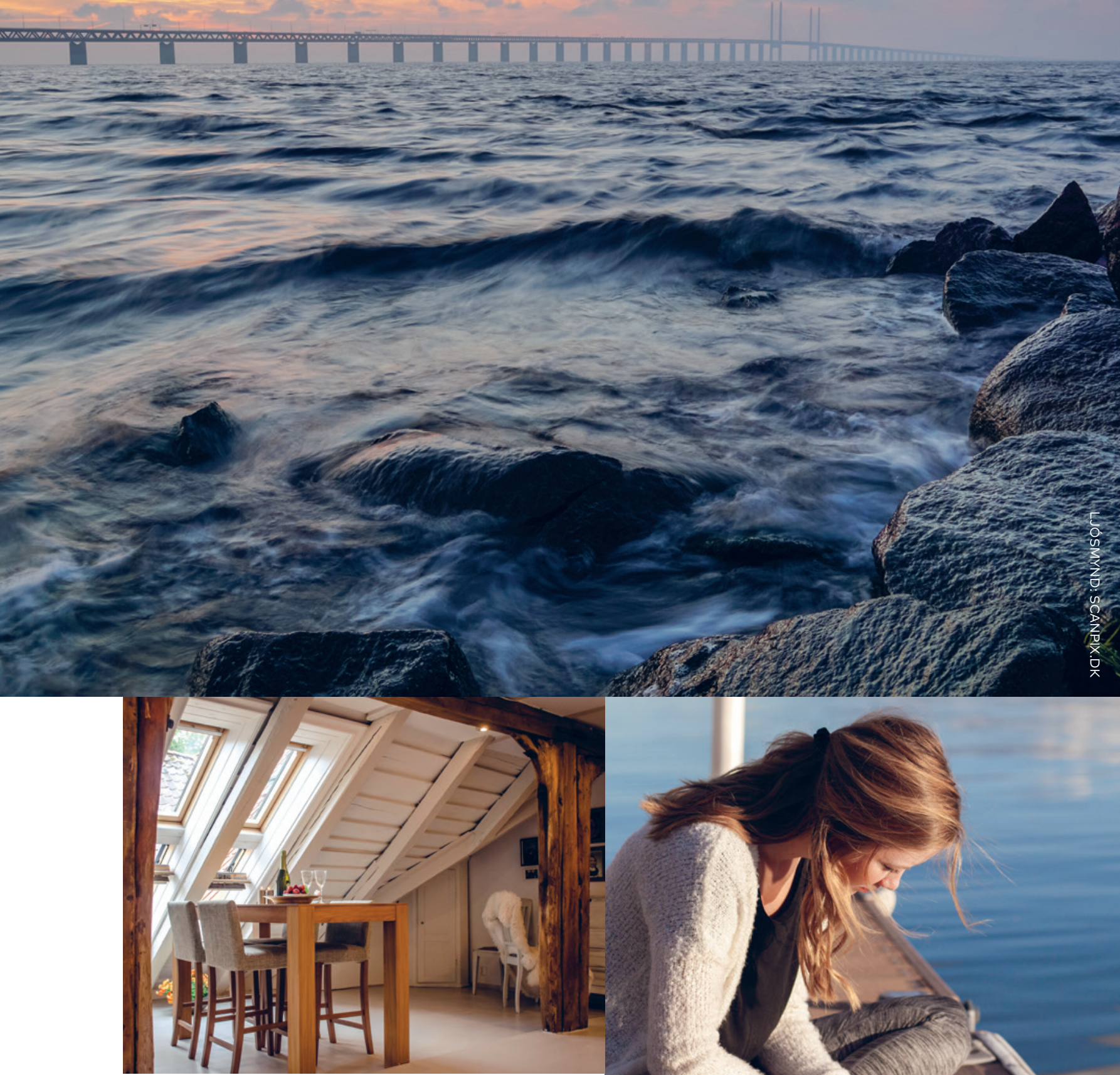

Stjórnsýsluhindranaráðið fékk aukið starfsumboð árið 2017 og mun framvegis hafa betri tól til að vinna að frjálsri för eða hreyfanleika innan Norðurlanda.

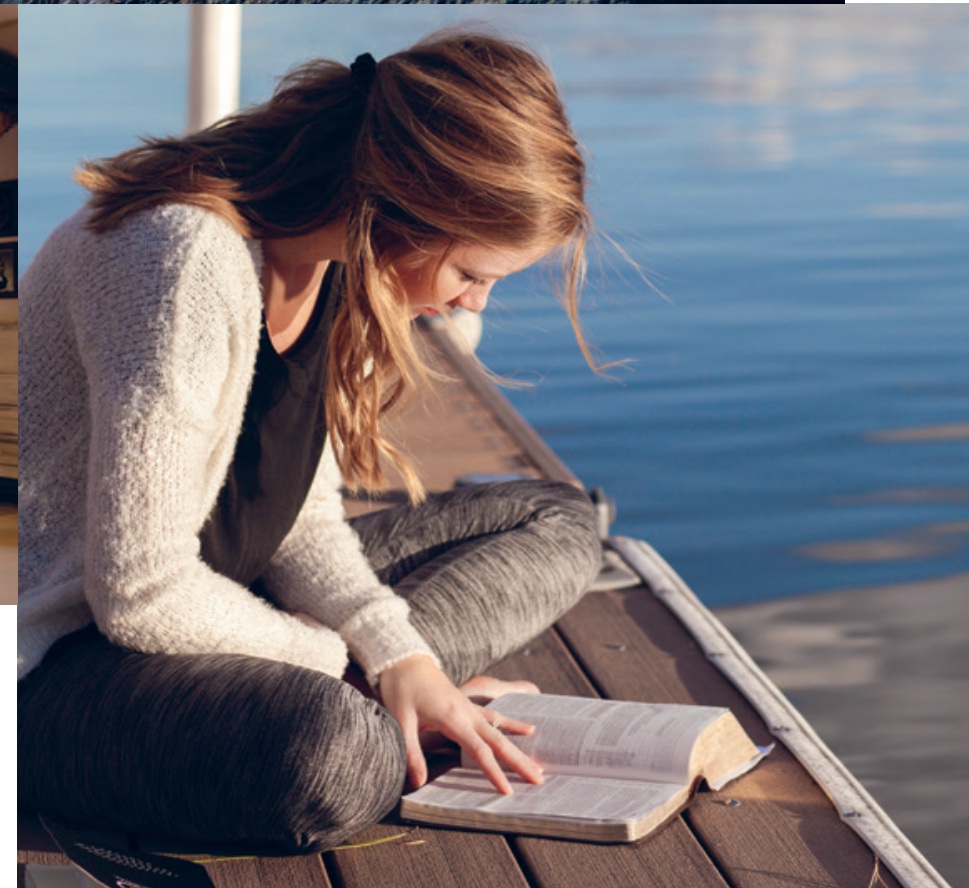




\section{Stjórnsýsluhindranarádiơ fær aukiò starfsumbod}

Eitt af mikilvægustu verkefnum norræns samstarfs er að greiða fyrir frjálsri för eða hreyfanleika innan Norðurlanda. Pað á að vera einfalt að flytja til annars norræns lands og að stunda nám, starfa og hefja atvinnurekstur á Norðurlöndum.

Stjórnsýsluhindranaráðið fékk nýtt og aukið starfsumboð 2017 en pað var liður í pví að stuðla enn frekar að frelsi og hreyfanleika. ÆEtlunin er að ráðið fái aukið pólitískt vægi til að geta rekið á eftir ríkisstjórnum landanna í málefnum sem varða frjálsa för. Forsætisráðherrarnir hafa lýst sýn sinni um að Norðurlönd verði best sampætta svæði heims og Stjórnsýsluhindranaráðinu er ætlað að vinna henni brautargengi.

Fulltrúar landanna fá meira svigrúm til að beita sér, til dæmis með pví að efna til funda með ráðherrum, aðilum vinnumarkaðarins og öðrum sem geta lagt eitthvað af mörkum við afnám stjórnsýsluhindrana. Verkefnið verður auk pess metnaðarfyllra par sem Stjórnsýsluhindranaráðinu er ætlað að prýsta á ríkisstjórnirnar að ryðja úr vegi átta til tólf stjórnsýsluhindrunum á ári, (áður fimm til tíu).
Á árinu 2017 greindi Stjórnsýsluhindranaráðið frá bví að tekist hafði að afgreiða átta hindranir sem stóðu hreyfanleika á Norðurlöndum fyrir prifum. Lausn fannst á sex peirra en úr tveimur var ekki unnt að leysa að svo stöddu.

Á árinu var opnuð vefgátt, á slóðinni www.nordenbusiness.org, sem á að auðvelda fyrirtækjum að fá yfirlit um lög og reglur í nágrannalöndunum um rekstur atvinnustarfsemi. Í gáttinni er safnað upplýsingum um reglur nágrannalandanna um skráningarkröfur, kröfur um viðurkenningu afurða, hvar beri að greiða skatt og hvar starfsfólk eigi að njóta almannatrygginga. Aðilar vinnumarkaðarins á Norðurlöndum hafa lagt mikla áherslu á að vefgáttin yrði að veruleika.

Um 70 púsund norrænir ríkisborgarar búa í öðru norrænu landi en peir starfa í. Starfsmenn sem fara á milli landa skila norrænu hagkerfi 5,3 milljónum evra sameiginlega auk pess sem löndin spara atvinnuleysisbætur svo að milljörðum skiptir. 

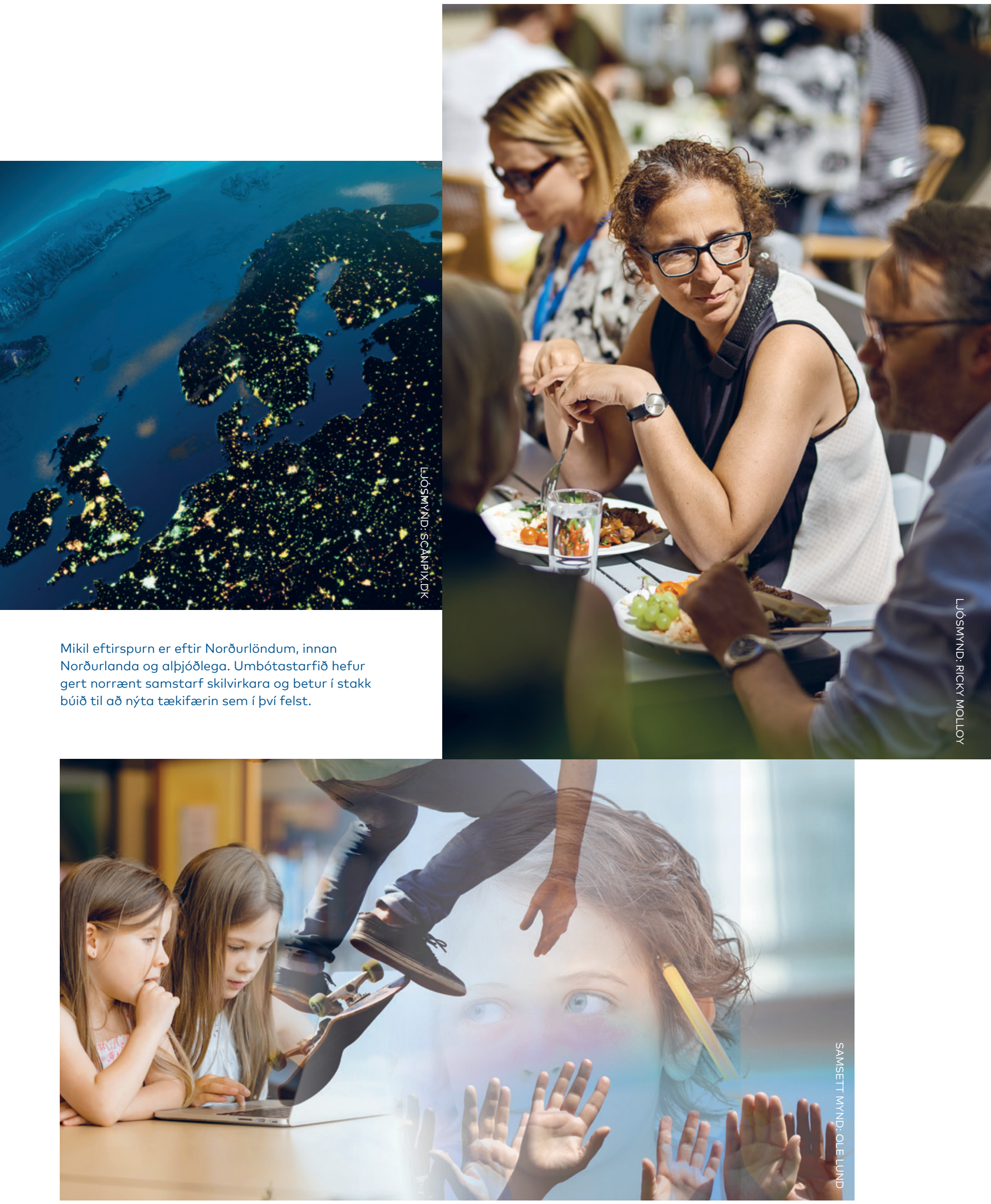


\section{Umbótastarfiő Nytt Norden skilar árangri}

Á undanförnum árum hafa verið gerðar

rækilegar umbætur á starfsemi Norrænu ráðherranefndarinnar og norrænu samstarfi undir yfirskriftunum Nytt Norden 1.0 og Nytt Norden

2.0. Tilgangurinn með umbótastarfinu hefur meðal annars verið að gera samstarfið kröftugra og pólitískara.

Áður en árið 2017 var liðið höfðu allar aðgerðir sem ákveðnar voru við upphaf umbótaferlisins verið framkvæmdar. Pótt umbæturnar hafi einnig áhrif á starfsemi Norrænu ráðherranefndarinnar á ókomnum árum pykir við hæfi að gera pær upp í lok árs 2017.

Snar páttur i umbótastarfinu voru stefnumótandi úttektir sem ráðist var í á nokkrum mikilvægum norrænum samstarfssviðum. Markmiðið var að greina svið par sem eru góðar horfur á öflugra norrænu samstarfi fimm til tíu ár fram í tímann. Tillögurnar í úttektunum setja mark sitt á pólitíska dagskrá samstarfsins, til að mynda á sviðum heilbrigðismála, vinnumála og orkumála. Á árinu 2018 verður áfram unnið að úttektum á ýmsum samstarfssviðum.
Með umbótunum var eindregið stefnt að skilvirkari starfsemi. Ákvörðunarferlið, starfshættir og innviðir hafa verið uppfærðir til að minnka bilið milli frumkvæðis og árangurs. Umbætur á fjárhagsáætlanagerðinni hafa leitt til betri markmiðs- og árangursstjórnunar og gefið kost á auknum sveigjanleika. Enn fremur hefur stýring norrænu stofnananna orðið skýrari og dregið hefur úr stjórnsýslukostnaði.

Innan ramma Nytt Norden hefur norrænt samstarf orðið mun alpjóðlegra. Sem dæmi má nefna að ráðherranefndin stendur að kynningu Norðurlanda erlendis á grundvelli vörumerkjaverkefnis. Alpjóðamál eru á dagskrá allra ráðherranefnda og löndin vinna nú orðið meira kerfisbundið saman en áður um ESBmál sem varða sameiginlega hagsmuni peirra. Löndin hafa tekið saman höndum um pungvæg alpjóðamál eins og loftslags- og umhverfismál.

Ágætt dæmi um samstarf með greinilegu albjóðlegu sjónarhorni er áðurnefnt verkefni forsætisráðherranna par sem Norðurlönd bjóða fram lausnir á hnattrænum viðfangsefnum. Reynslan sýnir að eftirspurn er eftir meiri Norðurlöndum á alpjóðavísu og innan Norðurlanda. Umbótastarfið hefur skilað sér í norrænu samstarfi sem er betur í stakk búið til að nýta pessi tækifæri. 


\section{Skapandil, sýnileg og opin Norôurlönd án landameara}




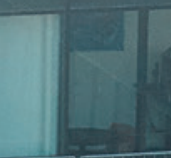

$\frac{-1}{4}$
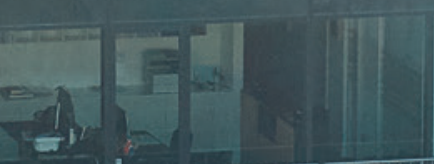


\section{Norræna ráŏherranefndin}

Nordens Hus

Ved Stranden 18

DK-1061 København K

www.norden.org

Peir níu hápunktar sem um er fjallað í pessu riti eiga að gefa yfirlit um starfsemi Norrænu ráoherranefndarinnar á árinu 2017. Pau viðfangsefni sem valin voru eru dæmi um nokkur forgangssvið á löngum lista verkefna og aðgerða sem settu svip sinn á starfsemi ráðherranefndarinnar árið 2017. 